\title{
Study of Freshwater Algae from Baramati City Area, District Pune
}

\author{
Snehal Dhumal, Rupali Chitale*, Ashwini Dudhal, \\ Harshal Wangikar and Prasad Bankar
}

P. G. Research Center, Department of Botany, Tuljaram Chaturchand College of Arts, Science and Commerce, Baramati, Dist. Pune - 413 102, Maharashtra, India

*Corresponding author

\section{A B S T R A C T}

\section{Keywords}

Chlorophycae (green algae), Bacillariophyceae (diatoms), Euglenophyceae and Cyanophyceae (blue green algae)

Article Info

Accepted:

24 September 2020

Available Online:

10 October 2020
The present investigation emphasizes on study of fresh water algae from surrounding area of Baramati city in Pune district of Maharashtra. Investigation shows that 23 genus algae were observed along with 25 species from 8 samples were isolated. These microalgae belonging to three major classes Chlorophyceae 11 sp., Bacillariophyceae 07 sp., Cyanophyceae 06 sp., Euglenophyceae 01 sp. and Batrachospermaceae 01 sp. Maximum algal genera belong to Chlorophyceae class was recorded.

\section{Introduction}

The group algae are cosmopolitan in nature that is found everywhere like oceans, lakes, rivers, ponds, puddles, moist surfaces and fresh water etc. (Desikachary, 1959). According to Chaterjee and Raziuddin (2006), fresh water ecosystems vary in size and composition and contain a large variety of organisms. Kumar and Amit (2012) investigated that Microalgae are vast group of prokaryotic and eukaryotic photosynthetic organisms found in many different forms viz. individual cells, colonies or extended filaments and exhibit vast diversity in the ecosystem. The algae plays important role as primary producers of water ecosystem for various consumers of aquatic fauna and rich source of protein, carbohydrates, minerals and especially essential fatty acids. These organisms have a major role in primary production, nutrient cycling and food web in the aquatic ecosystem (Dawes, 1998).

Algae are most helpful can be utilized in various fields such as food, feed, fine 
chemicals, bio energy and bioremediation. They are also rich source of proteins and other nutrients, like higher plants. Therefore, the present investigation has been carried out to algal diversity of freshwater algae from Baramati Area, along with the physicochemical parameters such as Total dissolved solids (TDS), Electrical Conductivity (EC), $\mathrm{pH}$ and Temperature of the water to interpret water quality.

\section{Materials and Methods}

\section{Study area}

This proposed work is done in nearby city area of Baramati, Dist. Pune in Maharashtra, India. In this about 8 sites have been screened for algal diversity studies. These all sites are along with Baramati city. Basically algal growth has been seen in and nearby water bodies. The 8 localities namely as 1.Canal road area 2.Kara river area 3.Water storage tank 4.Tandulwadi road area 5.Bhigwan road area 6.Indapur road area 7.Jalochi road area and 8.Sangavi road area.

\section{Collection and identification of algal samples}

Algal samples were collected in specimen glass bottles from different water bodies and resources in and around the city of Baramati area located in Pune district of Maharashtra. The samples collected from different sites were washed thoroughly with running tap water and then by distilled water for removal of any form of solid materials. Samples were then preserved using standard preservative of iodine solution and $4 \%$ formalin and were stored in glass containers for further use of macroscopic and microscopic study. Identification of the algal samples by microscopically by Digital Compound Optical Microscope with HD camera and identified with standard literature Prescott (1951) and Edmondson (1959).

\section{Results and Discussion}

In the presents investigation shows that 22 genus algae were observed along with 24 species from 8 samples was isolated. These microalgae belonging to three major classes Chlorophycae (green algae), Bacillariophyceae (diatoms), Euglenophyceae and Cyanophyceae (blue green algae). Maximum algal genera belong to green algae followed by blue green algae and diatoms. Present study reported tremendous diversity of algae containing 11Chlorophycae Chlorella vulgaris, Spirogyra fluviatilis, Spiryogyra ternate, Zygnema extenue, Zygnema circumcarinatum, Ulothrix zonata, Pithophora roettleri, Cladophora glomerata, Oedogonium sp, Chara braunii, Fragilaria sp. 07 Bacillariophyceae, Navicula oblonga, Gyrosigma acuminatum, Synedra ulna, Frustulia vulgaris, Tabellaria fenestrate, Pinnularia notate, Neidium affine, 05 Cyanophyceae, Chroococcus minutus, Microcystis aeruginos, Nostoc commune, Anabaena azollae, Oscillatoria limosa, 01Euglenophyceae, Euglena gracilis and 01 Batrachospermaceae, Batrachospermum Sp. species were recorded.

According to the parameters the amount of calcium is highest in water which is from Tandulwadi road area i.e. $1.35 \mathrm{mg} / \mathrm{L}$, while that of lowest is Tunnel canal area i.e. $0.75 \mathrm{mg} / \mathrm{L}$ and calcium amount of all other sites lies between these two. The magnesium is the essential factor which is highest $13.40 \mathrm{mg} / \mathrm{L}$ at Indapur road area and lowest at Tandulwadi area i.e. $10.25 \mathrm{mg} / \mathrm{L}$. Sodium which is known as microelement is highly present in Bhigwan road area which values $6.33 \mathrm{mg} / \mathrm{L}$. It is in less quantity in a Jalochi road area is $3.10 \mathrm{mg} / \mathrm{L}$.

In Chemical analysis amount of elements such as calcium, magnesium, sodium, potassium, bicarbonate, chlorine and sulphate 
were found from some water localities. Potassium is found in rare amount at all sites, some sites have no potassium. While its highest amount is found at Bhigwan road area which is $4.33 \mathrm{mg} / \mathrm{L}$. Bicarbonate is nothing but an intermediate form in de-protonation of carbonic acid. It is found equal at two sites i.e. at Tandulwadi and Tunnel canal area. It is found in huge quantity at Indapur road area. Sulphate is found very neglible in all localities except Tandulwadi road area. It is $0.1 \mathrm{mg} / \mathrm{L}$. According to Narwade et al., (2014) his investigated genus Spirogyra is considered to be inhabitant of unpolluted waters (Table 1 and 2).

Table.1 Algal species and their distribution

\begin{tabular}{|c|c|c|}
\hline $\begin{array}{l}\text { Sr. } \\
\text { No. }\end{array}$ & Name of algal species & $\begin{array}{l}\text { Total no. of localities in which sp. } \\
\text { Occurred }\end{array}$ \\
\hline \multicolumn{3}{|r|}{$*$ Chlorophyceae } \\
\hline 1. & Chlorella vulgaris & 5 \\
\hline 2 & Spirogyra fluviatilis & 7 \\
\hline 3 & Spiryogyra ternate & 5 \\
\hline 4 & Zygnema extenue & 1 \\
\hline 5 & $\begin{array}{l}\text { Zygnema } \\
\text { circumcarinatum }\end{array}$ & 5 \\
\hline 6 & Ulothrix zonata & 4 \\
\hline 7 & Pithophora roettleri & 2 \\
\hline 8 & Cladophora glomerata, & 2 \\
\hline 9 & Oedogonium sp. & 3 \\
\hline 10. & Chara brauni & 1 \\
\hline 11. & Fragilaria $s p$. & 6 \\
\hline \multicolumn{3}{|c|}{ * Bacillariophyceae } \\
\hline 1 & Navicula oblonga & 3 \\
\hline 2 & Gyrosigma acuminatum & 6 \\
\hline 3 & Synedra ulna & 3 \\
\hline 4 & Frustulia vulgaris & 3 \\
\hline 5 & Tabellaria fenestrate & 3 \\
\hline
\end{tabular}

\begin{tabular}{|c|c|c|}
\hline 6 & Pinnularia notate & 3 \\
\hline 7. & Neidium affine & 3 \\
\hline \multicolumn{3}{|c|}{ * Cyanophyceae } \\
\hline 1. & Chroococcus minutus, & 3 \\
\hline 2. & Microcystis aeruginosa & 5 \\
\hline 3. & Nostoc commune & 3 \\
\hline 4. & Anabaena azollae & 3 \\
\hline 5. & Oscillatorialimosa & 3 \\
\hline \multicolumn{3}{|c|}{ * Euglenaceae } \\
\hline 1 & Euglena gracilis & 3 \\
\hline \multicolumn{3}{|c|}{ * Batrachospermaceae } \\
\hline 1. & Batrachospermum sp. & 1 \\
\hline
\end{tabular}


Table.2 Physical analysis of water samples

\begin{tabular}{|c|l|c|c|c|c|}
\hline Sr.No. & Locality & TDS & EC & pH & Temp. \\
\hline 1. & Canal road area & 180.8 & 0.21 & 6.35 & $\mathbf{2 5}$ \\
\hline 2. & Kara river area & 170.7 & 0.20 & 6.11 & $\mathbf{2 3 . 3}$ \\
\hline 3. & Water storage tank & 145.5 & 0.25 & 6.05 & $\mathbf{2 1 . 2}$ \\
\hline 4. & Tandulwadi road area & 245.4 & 0.30 & 6.41 & $\mathbf{2 3 . 2}$ \\
\hline 5. & Bhigwan road area & 205.1 & 0.34 & 6.30 & $\mathbf{2 2 . 1}$ \\
\hline 6. & Indapur road area & 195.3 & 0.25 & 6.30 & $\mathbf{2 3 . 1}$ \\
\hline 7. & Jalochi road area & 93.50 & 0.15 & 7.65 & $\mathbf{2 3 . 5}$ \\
\hline 8. & Sangavi road area. & 93.66 & 0.10 & 6.13 & 23 \\
\hline
\end{tabular}

In conclusion, from this investigation, it shows that 24 species are observed in Baramati area. The highest algae found in Bhigwan road area are from Bacillariophyceae Cyanophyceae, are observed. The diatoms are very common in all areas except Tandulwadi road area. The unicellular forms like Chlorella of algae are found in Indapur road area. The physicochemical analysis of all water bodies contains high amount of calcium carbonate, which affects to the algal microflora. The other components present in water are $\mathrm{Ca}$, $\mathrm{Mg}, \mathrm{Na}, \mathrm{K}, \mathrm{HCo}_{3}, \mathrm{Cl}, \mathrm{SO}_{4}$. Water resources are also screened under parameters like TDS, $\mathrm{EC}, \mathrm{pH}$ and temperature etc. The higher value of temperature, alkality, chlorides, sulphate, sodium and bicarbonate influence the occurrence and abundance charophyceae, euglenophyceae and cyanophyceae algal forms.

\section{Acknowledgements}

Authors are sincerely thankful to Dr. Chandrashekhar Murumkar, Principal, Tuljaram Chaturchand College of Arts, Science and Commerce, Baramati, Dist. Pune. Sincerely thankful to Dr. S.J. Chavan Head, P. G. Research Center, Department of Botany, Tuljaram Chaturchand College of Arts, Science and Commerce, Baramati, Pune.

\section{References}

Chaterjee G and Raziuddin M. (2006) Status of water body in relation to some physico-chemical parameters in Asansol Town, West Bengal. Proc. Zool. Soc. India 5(2) 41-48

Dawes CJ. Marine Botany. 2nd Ed. John wiley and sons InC., New York; 1998.

Desikachary TV. (1959). Cyanophyta. Monograph on Blue Green Algae. Indian Council of Agricultural Research, New Delhi, India.

Edmondson WT. Fresh water Biology, II Ed John Wiley and sons Inc. New York 1959.

Indira $\mathrm{P}$ and Biswajit $\mathrm{R}$ Commercial and industrial applications of microalgae A review J. Algal Biomass Utln, 2012: 3(4); 89-100.

Jena M, Ratha SK and Adhikary SP. (2005) Algal diversity changes in Kathajodi River after receiving sewage of Cuttack and its ecological implications. Indian Hydrobiol., 8; 67-74.

Kumar J and Amit P. (2012) Water quality monitoring of Ken River of Banda District Uttar Pradesh, India. Elixir Journal- pollution, 42; 6360-6364.

Musharaf K Farrukh $\mathrm{H}$ and Shahana M A fraction of fresh water algae of Kalpani stream and adjoining area of district Mardan Pakistan. Int J Biosci, 
2011:145-50. 12.

Narwade K. B, Mulani R.M., Bhosle A. B., Yannawar V. B., (2014) Diversity of fresh water algae from the Sahastrakund waterfall, Nanded, Maharashtra. Indo American Journal of Pharmaceutical Research:4(03)

Philipose MT Chlorococcales, monograph on algae. Indian Council of Agricultural
Research, New Delhi, 1967.

Prescott GW. Algae of the western great lakes area, W.M.C Brown Publisher Dubuque, IOWA, USA 195.

Prescott GW. Algae of the Western Great Lakes area. Cranbrook Institute of Science, Bloomfield Hills, Michigan, USA, 1951. 14.

How to cite this article:

Snehal Dhumal, Rupali Chitale, Ashwini Dudhal, Harshal Wangikar and Prasad Bankar. 2020. Study of Freshwater Algae from Baramati City Area, District Pune. Int.J.Curr.Microbiol.App.Sci. 9(10): 2933-2937. doi: https://doi.org/10.20546/ijcmas.2020.910.353 